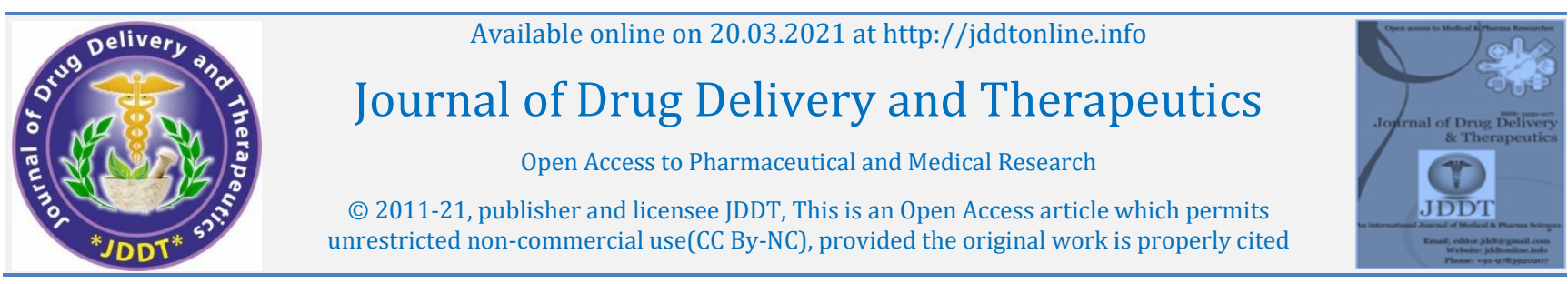

Open Access Full Text Article

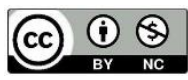

Research Article

\title{
Effect of Lanthanum Strontium Manganese Oxide (LaSMnO3) Nanoparticle on mouse Testosterone and Fertility
}

\author{
Olajumoke Omolara Ojo \\ Department of Biochemistry, Faculty of Science, Ekiti State University Ado-Ekiti, Ekiti State, Nigeria
}

\begin{tabular}{|c|c|}
\hline \multicolumn{2}{|c|}{ Article Info: } \\
\hline 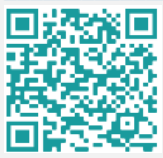 & $\begin{array}{l}\text { Article History: } \\
\text { Received 19 Jan 2021; } \\
\text { Review Completed 27 Feb } 2021 \\
\text { Accepted 09 March 2021; } \\
\text { Available online } 20 \text { March } 2021\end{array}$ \\
\hline \multicolumn{2}{|c|}{$\begin{array}{l}\text { Cite this article as: } \\
\text { Ojo O0, Effect of Lanthanum Strontium Manganese } \\
\text { Oxide }\left(\text { LaSMnO }{ }_{3} \text { ) Nanoparticle on mouse }\right. \\
\text { Testosterone and Fertility, Journal of Drug Delivery } \\
\text { and Therapeutics. } 2021 ; 11(2): 164-167 \\
\text { DOI: http://dx.doi.org/10.22270/jddt.v11i2.4614 }\end{array}$} \\
\hline $\begin{array}{l}\text { *Address fo } \\
\text { Olajumoke Omc } \\
\text { Biochemistry, F } \\
\text { University Ado }\end{array}$ & $\begin{array}{l}\text { Correspondence: } \\
\text { ara Ojo, Department of } \\
\text { culty of Science, Ekiti State } \\
\text { kiti, Ekiti State, Nigeria }\end{array}$ \\
\hline
\end{tabular}

\subsection{INTRODUCTION}

Considerable research interest in the area of drug delivery using particulate delivery systems as carriers for small and large molecules. Nanoparticles system have been used as a physical approach to alter and improve the pharmacokinetic and pharmaco-dynamics properties of various types of drug molecules especially most of the anti-cancer drugs, hence used in-vivo to protect the drug entity in the systemic circulation, restrict access of the drug to the chosen sites and to deliver the drug at a controlled and sustained rate to the site of action. Various polymers have been used in the formulation of nanoparticles for drug delivery research to increase therapeutic benefit, while minimizing side effects. Polymeric nanoparticles offer some specific advantages over liposomes, they help to increase the stability of drugs/proteins and possess useful controlled release properties ${ }^{1,2}$. However, the safety of these carriers has been questioned. This study is therefore designed to evaluate the effect of this new nanoparticle on male fertility.

\subsection{MATERIALS AND METHODOLOGY}

Lanthanum strontium manganese oxide $\left(\mathrm{LaSMnO}_{3}\right)$ (synthesized in the laboratory), Nitro blue tetrazolium (NBT), Sodium chloride $(\mathrm{NaCl})$, Sodium azide, Bradford reagent, Sodium pyrophosphate, Sodium acetate \&Sodium hydroxide $(\mathrm{NaOH}) \mathrm{Na}_{2} \mathrm{HPO}_{4}$ (Disodium hydrogen phosphate; dibasic), Potassium dihydrogen phosphate $\left(\mathrm{KH}_{2} \mathrm{PO}_{4}\right)$, Glycine, Sodium citrate, $\mathrm{NaH}_{2} \mathrm{PO}_{4} .2 \mathrm{H}_{2} \mathrm{O}$ (Sodium dihydrogen Phosphate hydrated monobasic) were procured from Sigma, USA.

\subsection{Experimental animals}

Male and female mice were obtained from animal house of Ekiti-State University Ado Ekiti, Nigeria. The animals were maintained under standard conditions of humidity $(50 \pm 5$ $\%)$, temperature $\left(25 \pm 2{ }^{\circ} \mathrm{C}\right)$ and dark and light cycles (12 hrs each) with free access to food and water.

\subsection{Dose grouping}

The animals were divided into 4 groups $(n=5)$. Group I served as control while groups II, III, and IV received 5,10 , and $20 \mu \mathrm{g} / \mathrm{kg} /$ day of $\mathrm{LaSMnO}_{3}$ respectively. Five animals from each group were sacrificed at interval of 0 day 7 days, 14 days, and 21 days following administration of $\mathrm{LaSMnO}_{3}$ Oxide prepared in Dimethyl Sulfoxide (DMSO) via intraperitoneal injection. On the twenty-one days, treated male mice of all groups were cohabited with untreated female mice for fertility study.

\subsection{Tissue Sampling}

At autopsy, Epididymis and testis were removed, blotted free of blood and adhering tissues, kept in tube and immediately stored in $-20^{\circ} \mathrm{C}$ for biochemical studies.

\subsection{Testosterone estimation}

The testicular testosterone level from each group was measured ${ }^{3}$. Briefly, testicular proteins were extracted with phosphate buffer (50 mM, pH 7.4) and centrifuged at 10,000 $\mathrm{g}$ for $20 \mathrm{~min}$. The supernatant was used to estimate testosterone level using ELISA method and were expressed in $\mathrm{ng} / \mathrm{ml}$. 


\subsection{Measurement of Reactive Oxygen Species (ROS) Level}

Briefly, $50 \mu \mathrm{l}$ of epididymis homogenate and $1400 \mu \mathrm{l}$ sodium acetate buffer were transferred to a cuvette. After then, 1000 ul of reagent mixture $(\mathrm{N}, \mathrm{N}$-diethyl para phenylenediamine $6 \mathrm{mg} / \mathrm{ml}$ with $4.37 \mu \mathrm{M}$ of ferrous sulfate dissolved in $0.1 \mathrm{M}$ sodium acetate buffer $\mathrm{pH}-4.8$ ) was added at $37{ }^{\circ} \mathrm{C}$ for $5 \mathrm{~min}$. The absorbance was measured at $505 \mathrm{~nm}$ using spectrophotometer (Molecular Devices.) ROS levels from the tissue were calculated from a calibration of $\mathrm{H}_{2} \mathrm{O}_{2}$ and expressed as $\mathrm{U} / \mathrm{mg}$ of protein ( 1 unit=1.0 $\mathrm{mg} \mathrm{H}_{2} \mathrm{O}_{2} / \mathrm{L}$ ).

\subsection{Biomarkers enzymes analyses}

$10 \%$ epididymis homogenates $(\mathrm{w} / \mathrm{v})$ was prepared in chilled $100 \mathrm{mM}$ Phosphate buffer ( $\mathrm{pH} 7.4$ ) and the homogenate was used to measure the levels of GSH and CAT measured according to the standard protocols ${ }^{4,5}$. Protein contents in the samples were estimated by the Bradford method. All the parameters were expressed as per mg protein.

\subsection{Sperm parameters}

Cauda epididymidis was removed from each mouse and cleaned off from the epididymal fat pad, and minced in a prewarmed petri dish containing $500 \mu \mathrm{l}$ phosphate buffer saline solutions (PBS, pH 7.4) at $37^{\circ} \mathrm{C}$. Sperm motility was estimated and expressed as percentage incidence 6 . For sperm count, an aliquot of this suspension was charged into the Neubauer's counting chamber and the spermatozoa were counted under light microscope. Total sperm count was calculated as the average of the spermatozoa count $(\mathrm{N})$ in each chamber X multiplication factor (106) X dilution factor and was expressed in millions $/ \mathrm{ml} \mathrm{7,} \mathrm{8.} \mathrm{The} \mathrm{sperm}$ morphology was also evaluated ${ }^{9}$. Briefly, a smear of sperm was made on a clean slide and stained with hematoxylin and eosin and were examined under a light microscope with an oil immersion lens. The morphology of spermatozoa was scored according to Qureshi et al., 8 .

\subsection{Incidence of Implantation and dominant lethality}

Male fertility was checked in mice of groups V, VI, VII, and VIII following treatment according to standard method scored 9,10 . Each male was caged with one female per week for four weeks. The females were sacrificed on 13 days of mating to check implantation. The number of pregnant mice was recorded to determine percent of fertility 11,12. The incidence of pregnancy was established after counting the number of implants. The dead implants per female were determined to obtain the post-implantation loss Agrawal 13 Fertility index was calculated by the ratio of the number of pregnant females to number of females cohabited with males multiplied by 100 .

\subsection{Statistical analysis}

Statistical comparisons between the groups were analyzed using Statistical Package (SPSS version 22). The results were expressed as mean \pm SEM. Significant differences among means of the groups were determined using one-way analysis of variance (ANOVA) and where significant difference existed, it was followed by Duncan's multiple range tests. Mean was considered significant when $p \leq 0.05$.

\subsection{RESULTS}

3.1. Testicular testosterone level was found to be reduced in all $\mathrm{LaSMnO}_{3}$-treated mice. Significant dose-dependent depletion of testicular testosterone was seen across all the groups (Table 1).

Table 1: Effect of $\mathrm{LaSMnO}_{3}$ Nanoparticle on Testicular Testosterone

\begin{tabular}{|lllll|}
\hline \multicolumn{5}{c|}{ Testosterone $(\mathrm{ng} / \mathrm{ml})$} \\
\hline Dose Groups & Day 0 & Day 7 & Day 14 & Day 21 \\
\hline Group I & $7.82 \pm 0.29$ & $7.97 \pm 0.12$ & $8.02 \pm 0.02$ & $8.07 \pm 0.12$ \\
Group II & $7.99 \pm 0.23$ & $5.17 \pm 0.12^{*}$ & $4.78 \pm 0.02^{* *}$ & $4.37 \pm 0.12^{* *}$ \\
Group III & $7.85 \pm 0.11$ & $4.18 \pm 0.17^{* *}$ & $3.52 \pm 0.23^{* * *}$ & $2.75 \pm 0.32^{* * *}$ \\
Group IV & $7.54 \pm 0.17$ & $2.48 \pm 0.25^{* *}$ & $1.89 \pm 0.01^{* * *}$ & $0.83 \pm 0.25^{* * *}$ \\
\hline \multicolumn{7}{l}{ Note: ${ }^{* *}$, and ${ }^{* * *}$ Indicate significant difference as compared to control at $(\mathrm{p}<0.001),(\mathrm{p}<0.01)$ and $(\mathrm{p}<0.05)$ respectively. }
\end{tabular}

\subsection{Effect of $\mathrm{LaSMnO}_{3}$ on Reactive Oxygen Species}

Significant raised level of Reactive Oxygen Species (ROS) in groups II, III and VI compared to the control was measured across all the groups in dose-dependent pattern confirming generation of reactive oxygen species following $\mathrm{LaSMnO}_{3}$ exposure.

\subsection{Effect of $\mathrm{LaSMnO}_{3}$ on GSH and CAT}

Significant decrease $(p<0.01)$ in the concentration of reduced glutathione and catalase was seen in the epididymal homogenate of $\mathrm{LaSMnO}_{3}$-treated mice following 21 days exposure in dose-dependent manner across all the groups. Oxidative stress was induced by $\mathrm{LaSMnO}_{3}$ treatment as confirmed by the depletion of these biomarkers (Figure 2 a \& b).

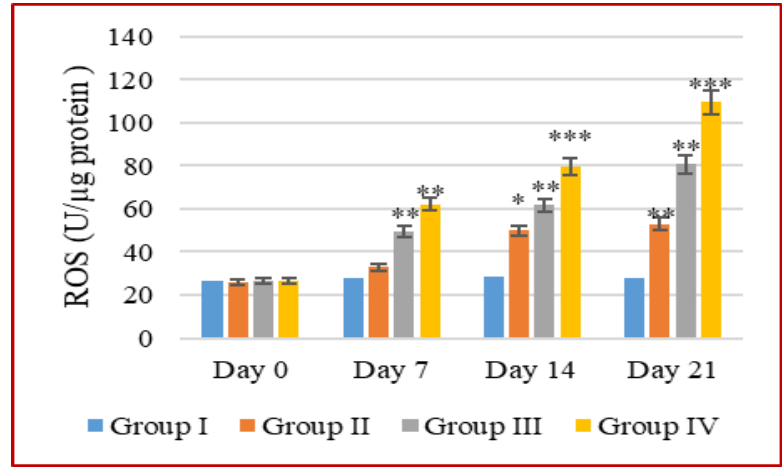

Figure 1: Barchat showing effect of $\mathrm{LaSMnO}_{3}$ on reactive oxygen species. Note: ${ }^{*}, * *$, and ${ }^{* * *}$ Indicate significant difference as compared to control at $(p<0.001),(p<0.01)$ and $(\mathrm{p}<0.05)$ respectively 


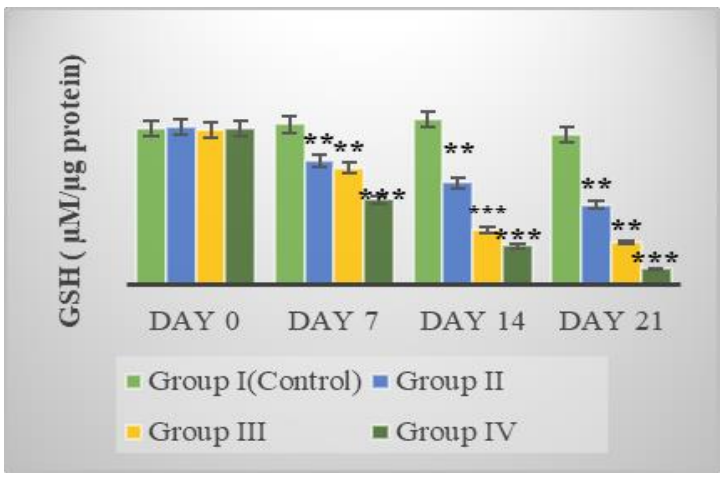

(a)

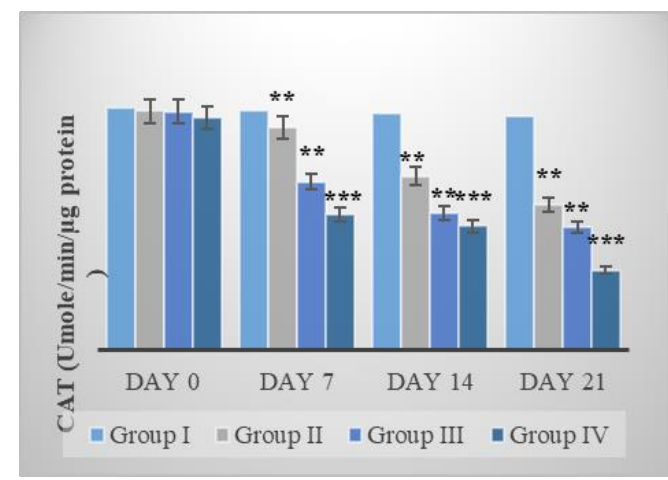

(b)

Figure 2: Barchat showing effect of $\mathrm{LaSMnO}_{3}$-treatment on (a)GSH, (b) CAT in epididymal tissue of mice. Note: *, **, and *** Indicate significant difference as compared to control at $(\mathrm{p}<0.001),(\mathrm{p}<0.01)$ and $(\mathrm{p}<0.05)$ respectively

\subsection{Effect on Sperm Parameters}

$\mathrm{LaSMnO}_{3}$-treatment caused a significant decrease number of epididymal spermatozoa (Figure 3a) and motility (3b) $(\mathrm{p}<0.001)$ when compared to control and a marked increase $(\mathrm{p}<0.01)$ in abnormal spermatozoa morphology $(3 \mathrm{c})$ was observed in epididymal spermatozoa of mice following 14 and 21 days treatment of $\mathrm{LaSMnO}_{3}$ nanoparticle.

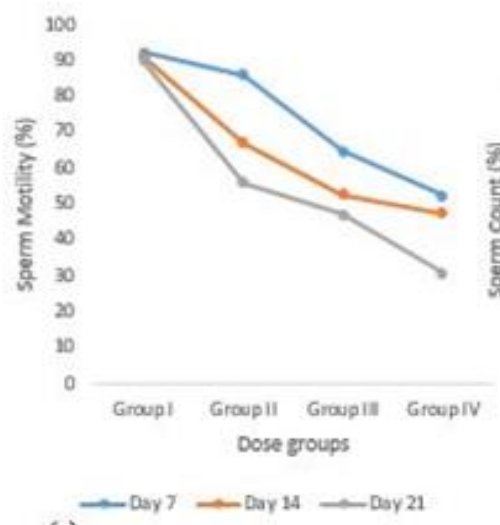

(a)

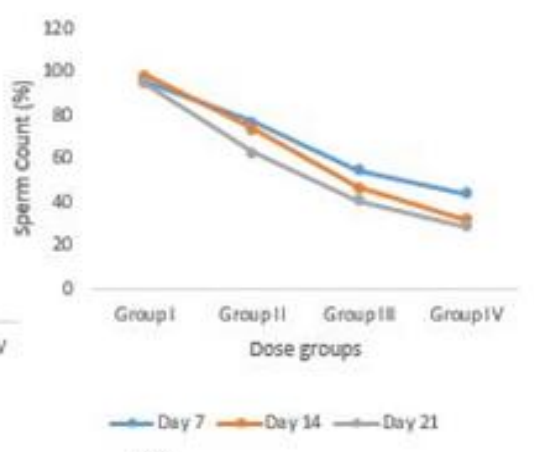

(b)

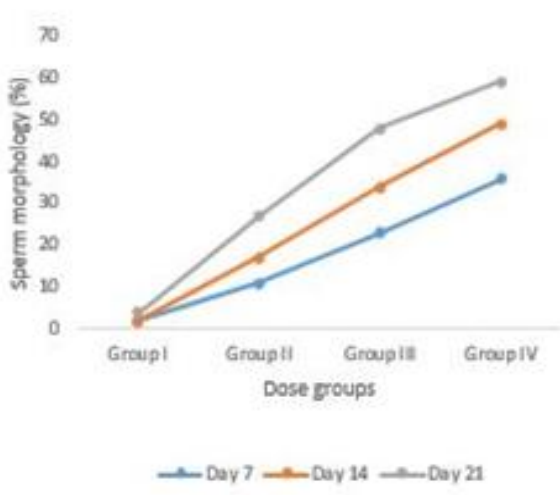

(c)

Figure 3: Effect of $\mathrm{LaSMnO}_{3}$-treatment on sperm parameters, Figure 3(a) shows percentage rate of spermatozoa motility, (b) sperm count and (c) abnormal morphology of the spermatozoa.

\subsection{Male fertility and dominant lethality}

Low incidence of pregnancy and implantation in females mated with $\mathrm{LaSMnO}_{3}$ nanoparticle -treated males was observed after 21 days exposure confirming the infertility potential of this nanoparticle (Table 2).

Table 2: Effect of $\mathrm{LaSMnO}_{3}$ Nanoparticle on Incidences of pregnancy in female cohabited with treated male mice

\begin{tabular}{|l|l|l|l|l|l|}
\hline Dose Groups/ Day 21 & Pregnant female & Male Fertility Index (\%) & \multicolumn{3}{|c|}{ Average No of Implants/ Female \pm S.E.M } \\
\hline & & & Total & Live & Dead \\
\hline Group I & $18 / 20$ & 90 & $16.35 \pm 0.22$ & $14.34 \pm 0.16$ & $2.01 \pm 0.01$ \\
\hline Group II & $12 / 20$ & 60 & $13.11 \pm 0.14^{* *}$ & $11.29 \pm 0.11^{* *}$ & $1.82 \pm 0.03$ \\
\hline Group III & $5 / 20$ & 25 & $6.54 \pm 0.07^{* * *}$ & $5.22 \pm 0.06^{* * *}$ & $1.32 \pm 0.01$ \\
\hline Group IV & 02 & $2.00 \pm 0.01^{* * *}$ & 0 & $2.00 \pm 0.01$ \\
\hline
\end{tabular}

Note: ${ }^{* * *}$, and ${ }^{* * *}$ Indicate significant difference as compared to control at $(\mathrm{p}<0.001),(\mathrm{p}<0.01)$ and $(\mathrm{p}<0.05)$ respectively

\section{DISCUSSIONS}

Nanomaterials are integral components of daily-used products including food, sunscreens, cosmetics and pharmaceutics and have been reported to be among factors that influence development of various medical conditions including reproductive disorders. Despite the benefits of nanoparticles, various applications of nanotechnology have exposed humans and animals to their potential toxicities.
Exposure of nanoparticle into the body can be through inhalation, ingestion, skin uptake, injection, or implantation and nanoparticles uptake which could be intentional or nonintentional 14. Thus, the wide use of nanomaterials has raised concerns about the negative impact to human health, mainly on the reproductive systems of both men and women. Research studies on nanoparticles are associated with different disorders in animals, including, hepatotoxicity, neurotoxicity, renal toxicity, and irreversible 
testis damage 15, 16, 17 with few reports on the effect of nanoparticles on male fertility.

This study therefore shows significant depletion of the testicular testosterone hormone across all the groups treated with Lanthanum strontium manganese oxide $\left(\mathrm{LaSMnO}_{3}\right)$ nanoparticle. This reduction was significant at 7 days dosing with the peak after 21 days treatment which implies that Lanthanum nanoparticle destroys the functions of testis of the treated mice which are mainly the productions of sperm and testosterone.

This study also revealed that micrograms concentration of Lanthanum nanoparticles in mice decreases epididymal sperm motility and marked reduction of spermatozoa numbers in dose-dependent patterns was also measured. The abnormal spermatozoa morphology significantly increased across all the dose groups. Similar report on nanoparticles showed decreases motility of human sperm. ${ }^{18}$ The decrease in the numbers of spermatozoa indicates the cytotoxicity effects of this nanomaterial, Lanthanum strontium manganese oxide $\left(\mathrm{LaSMnO}_{3}\right)$ resulting to testicular tissue dysfunction. Report have shown that $\mathrm{TiO}_{2}$ nanoparticle leads to alteration in testicular morphology and reduction in daily sperm production. ${ }^{19}$ Similar study also showed maternal exposure to diesel exhaust particles enhances mutations in male germlines during development ${ }^{20}$. More so, decreased sperm production has been associated with alteration in the overall expression of genes involved in spermatogenesis 21,22 .

The nanoparticles-mediated toxicity remains major focus of many researchers, however, little is known till now in vivo, hence this study showed that Lanthanum Strontium Manganese Oxide $\left(\mathrm{LaSMnO}_{3}\right)$ administration in male mice induces reproductive toxicity by increasing intracellular reactive oxygen species (ROS) levels of vital reproductive organ with simultaneous significant $(\mathrm{p}<0.05)$ depletion of CAT and GSH, anti-oxidant biomarkers in the epididymis across all the treated groups especially, in the groups treated with $20 \mu \mathrm{g} / \mathrm{kg} /$ day of $\mathrm{LaSMnO}_{3}$ when compared to control mice Nanoparticle has been reported to induce ROS by altering the homeostatic redox state of the host resulting to oxidative stress in the tissues, this may also be the case in the administration of $\mathrm{LaSMnO}_{3} .{ }^{23,24,25}$

\section{CONCLUSION}

This study established that the reproductive health of male mice used in this study is severely impaired following Lanthanum Strontium Manganese Oxide $\left(\mathrm{LaSMnO}_{3}\right)$ treatment. The study clearly shows reduction of testosterone, epididymal sperm motility and increased abnormal spermatozoa morphology after the administration of this Lanthanum nanomaterial. This study also revealed the generation of oxidative stress in the epididymis after the treated as confirmed by the increase level of reactive oxygen species and simultaneous depletion of anti-oxidant biomarkers which could be the reason for the cytotoxicity of spermatozoa seen in the treated mice. This study further shows that $\mathrm{LaSMnO}_{3}$-treatment results in male infertility. Finally, this study has been able to give insight on the reproductive toxicity of Lanthanum Strontium Manganese Oxide $\left(\mathrm{LaSMnO}_{3}\right)$ nanoparticles. Further study is therefore required to clearly understand the mechanism involved.

Competing Interests: The authors have declared that no competing interests exist
Acknowledgement: The author acknowledges all P1 Research team and Mr. Oyewumi Titiloye John of Chemical Pathology Department, College of Medicine, University of Ibadan Oyo-State Nigeria.

\section{REFERENCES}

1. Taylor R, Coulombe S, Otanicar T, Phelan P, Gunawan A, Lv W, Rosengarten G, Prasher R, Tyagi H, Small particles, big impacts: A review of the diverse applications of nanofluids, Journal of Applied Physics, 201; 113:011301.

2. Vert M, Doi Y, Hellwich KH, Hess M, Hodge P, Kubisa P, Rinaudo M, Schué FO, Terminology for biorelated polymers and applications, Pure and Applied Chemistry, 2012; 84 (2):234-267

3. Rocha JS, Bonkowski MS, Franca LR, Bartke A, Mild caloric restriction does not affect testosterone levels and testicular gene in mutant mice, Exp Biol Med, 2007; 232:1050- 1063.

4. Habig WH, Pabst MJ, Jakoby WB, Glutathione S-transferases. The first enzymatic step in mercapturic acid formation, J. Biol. Chem,1974; 249:7130-7139.

5. Aebi H, Catalase IN, Bergmeyer HU, Methods in Enzymatic Analysis Academic Press New York, 1983; 276-286.

6. Anderson D, Antioxidant defenses against reactive oxygen species causing genetic and other damage, Mutat. Res.1996; 350:103-108.

7. Wyrobek AJ, Bruce WR, Chemical induction of sperm abnormalities in mice. Proc. Natl Acad Sci, 1975; 7(11):4425-4429.

8. Qureshi S, Tariq M, Parmar NS, Al-Meshal IA, Cytological effects of Khat (Catha edulis) in somatic and male germ cells of mice. Drug Chem Toxicol, 1988; 11:151-165

9. Wyrobek AJ, Gordon LA, Burkhart JG, Francis MW, Kapp, RW, Letz G, Malling HV. et al, An evaluation of human sperm as indicators of chemically induced alterations of spermatogenic function: a report of the U.S. Environmental Protection Agency Gene-Tox Program, Mutat Res, $1983 ; 115: 73-148$.

10. Ojo 00, Bhadauria S, Rath SK, Dose-Dependent Adverse Effects of Salinomycin on Male Reproductive Organs and Fertility in Mice, PLoS ONE 2013; 8(7): e69086. doi:10.1371/journal.pone.0069086.

11. Coppola JA, An extragonadal male antifertility agent., Life Science, 1969 8:43-48.

12. Al-Shabanah, OA, Influence of captopril on spermatogenic dysfunction, spermatocyte chromosomes and dominant lethality in Swiss albino male mice, Research Communications in Pharmacology and Toxicology, 1997; 69-84.

13. Agrawal RC, Shukla Y, Mehrotra NK, Assessment of mutagenic potential of thiram. Food and Chemical Toxicology. 1997; 523-525.

14. Yah CS, Simate GS, and Iyuke, SE, Nanoparticles toxicity and their routes of exposures. Pak. J Pharm, Sci, 2012; 25:477-491.

15. Chou CC, Hsiao HY, Hong QS, Chen CH, Peng YW, Chen HW, et al, Singlewalled carbon nanotubes can induce pulmonary injury in mouse model. Nano Lett, 2008; 8: 437-445. doi: 10.1021/nl0723634.

16. Lin $\mathrm{P}$, Chen JW, Chang LW, Wu JP, Redding L, Chang $\mathrm{H}$, et al, Computational and ultrastructural toxicology of a nanoparticle, Quantum Dot 705 in mice. Environ. Sci Technol, 2008; 42: 6264-6270. doi: 10.1021/es800254a.

17. Wu YL, Piao DM, Han XH, Nan JX, Protective effects of salidroside against acetaminophen-induced toxicity in mice, Biol Pharm Bull 2008; 31:15231529.

18. Takeda K, Suzuki KI, Ishihara A, Kubo-Irie M, Fujimoto R, Tabata M, et al, Nanoparticles transferred from pregnant mice to their offspring can damage the genital and cranial nerve systems, J. Health Sci, 2009; 55:95102 doi: $10.1248 /$ jhs.55.95.

19. Boisen, AMZ, Shipley T, Jackson P, Wallin H, Nellemann, C, Vogel U, et al, In utero exposure to nanosized carbon black (Printex90) does not induce tandem repeat mutations in female murine germ cells. Reprod. Toxicol. 2013; 41:45-48. doi: 10.1016/j.reprotox.2013.06.068.

20. Lan Z and Yang WX, Nanoparticles and spermatogenesis: how do nanoparticles affect spermatogenesis and penetrate the blood-testis barrier. Nanomedicine, 2012; 7:579-596. doi: 10.2217/nnm.12.20.

21. Hong F, Zhao X, Chen M, Zhou Y, Ze Y, Wang L, et al, TiO2 nanoparticlesinduced apoptosis of primary cultured Sertoli cells of mice. J. Biomed. Mater. Res. Part A , 2016; 104:124-135. doi: 10.1002/jbm.a.35548.

22. Khanna P, Ong C, Bay BH, and Baeg GH, Nanotoxicity: an interplay of oxidative stress, inflammation and cell death. Nanomaterials, 2015; 5:1163-1180. doi: 10.3390/nano5031163

23. McShan, D, Ray PC, and Yu H, Molecular toxicity mechanism of nanosilver J Food Drug Analysis 2014; 22:116-127. doi: 10.1016/j.jfda.2014.01.010.

24. Brohi RD, Wang L, Talpur HS, Wu D, Khan FA, Bhattarai D, Rehman ZU, Farmanullah F and Huo LJ, Toxicity of Nanoparticles on the Reproductive System in Animal Models: A Review. Front. Pharmacol. 2017; 8:606. doi: 10.3389/fphar.2017.00606. 